\title{
Pengolahan Limbah Tongkol Jagung Menjadi Asap Cair dengan Metode Pirolisis Lambat
}

\author{
Muallim Syahrir ${ }^{1, a}$ dan Mahyati ${ }^{1, b}$ \\ ${ }^{1}$ Jurusan Teknik Kimia Politeknik Negeri Ujung Pandang, Jl. Perintis Kemerdekaan \\ KM 10, Makassar 90245, Indonesia \\ amuallimsyahrir@yahoo.com \\ bmahyatikimia@poliupg.ac.id
}

\begin{abstract}
The purpose of this study was to determine the temperature, time and the optimum size of the pyrolysis process to yield liquid smoke, and to know the grade of liquid smoke. Pyrolysis process were done by varying the temperature $350^{\circ} \mathrm{C}$, $400^{\circ} \mathrm{C}, 450^{\circ} \mathrm{C}, 500^{\circ} \mathrm{C}$, the time variation of 30 minutes, 60 minutes, 90 minutes, 120 minutes, 150 minutes, 180 minutes and a variety of fine size $(3 / 8$ inch $)$, medium $(1$ inch $)$, coarse $(1.5$ inches), after the analysis of $\mathrm{pH}$, specific gravity, acid tertitrasi and total phenol content analysis. Liquid smoke that optimum results are calculated to determine whether the economic feasibility of this research can be continued at the industrial stage. The research showed the optimum temperature of $400^{\circ} \mathrm{C}$ at a yield of $45.5 \%$, the optimum time of 120 minutes resulted in a yield of $46 \%$ and smoother optimum size at a yield of $47 \%$. Total acid is between $6.8054 \%-7.2746 \%$, pH between 1.8 to 1.9 with phenol levels between $3.4456 \%-4 \%$ in 1569 to produce liquid smoke to grade 4.
\end{abstract}

Keywords—liquid smoke, pyrolysis, waste corn stalks, yield

\begin{abstract}
Abstrak-Tujuan penelitian ini adalah untuk mengetahui suhu, waktu dan ukuran optimum pada proses pirolisis terhadap yield asap cair, serta mengetahui grade asap cair. Proses pirolisis dilakukan dengan variasi suhu $350^{\circ} \mathrm{C}, 4_{00}^{\circ} \mathrm{C}, 450^{\circ} \mathrm{C}, 500^{\circ} \mathrm{C}$, variasi waktu 30 menit, 60 menit, 90 menit, 120 menit, 150 menit, 180 menit dan variasi ukuran halus (3/8 inci), sedang ( 1 inci), kasar (1,5 inci), setelah itu dilakukan analisa $\mathrm{pH}$, berat jenis, total asam tertitrasi dan analisa kadar fenol. Hasil asap cair yang optimum dihitung kelayakan ekonominya untuk mengetahui apakah penelitian ini dapat dilanjutkan pada tahap industri. Berdasarkan hasil penelitian diperoleh suhu optimum $400^{\circ} \mathrm{C}$ dengan yield sebesar $45,5 \%$, waktu optimum 120 menit menghasilkan yield sebesar $46 \%$ dan ukuran optimum halus dengan yield sebesar $47 \%$. Total asam tertitrasi yaitu antara $6,8054 \%-7,2746 \%$, pH antara 1,8 - 1,9 dengan kadar fenol antara $3,4456 \%-4,1569 \%$ menghasilkan asap cair dengan grade 4.
\end{abstract}

Kata Kunci-asap cair, limbah tongkol jagung, pirolisis, yield

\section{Pendahuluan}

Tongkol jagung merupakan limbah tanaman jagung. Limbah tanaman jagung ini biasa dikenal dengan nama biomassa jagung. Proporsi biomassa jagung dari tongkol adalah 20\% [1], Produktivitas jagung tahun 2015 mencapai 19.611.704 ton.

Kandungan utama dalam tongkol jagung adalah lignoselulosa yang merupakan gabungan antara selulosa, hemiselulosa, dan lignin. Kandungan bahan ini akan mengalami proses dekomposisi melalui proses pirolisis. Proses pirolisis tongkol jagung, setelah dianalisa didapatkan hasil dekomposisi selulosa terjadi pada suhu $340^{\circ} \mathrm{C}$, hemiselulosa pada suhu $220^{\circ} \mathrm{C}$ dan $280^{\circ} \mathrm{C}$, lignin pada suhu $310^{\circ} \mathrm{C}$ [2].

Proses pirolisis menghasilkan tiga komponen yaitu cairan, gas dan padatan. Padatan hasil pirolisis limbah tongkol jagung selanjutnya akan diolah menjadi briket batubara. Briket adalah bahan bakar padat dengan bentuk dan ukuran tertentu yang tersusun dari butiran halus dan bahan yang mengandung karbon tinggi seperti tongkol jagung yang nantinya akan di blending dengan batubara untuk meningkatkan nilai kalor. Hasil asap cair yang diperoleh dapat digunakan sesuai dengan grade asap cair diantaranya sebagai pestisida penyemprotan buah dan sayuran, pengawetan ikan dll.

Pengolahan limbah tongkol jagung dengan metode pirolisis lambat merupakan suatu penelitian yang berpotensi untuk meningkatkan nilai ekonomis limbah tongkol jagung. Dengan memvariasikan suhu, ukuran dan waktu tinggal akan didapatkan grade asap cair dengan kondisi optimum sesuai dengan peruntukannya. 
Pirolisis adalah proses dekomposisi kimia dari zat organik melalui pemanasan tanpa adanya oksigen . Teknik ini dikembangkan untuk menghasilkan bio energi dan produk dari bahan baku biomassa . suhu pirolisis biomassa berkisar antara $350-550^{\circ} \mathrm{C}$ dan mencapai hingga $700^{\circ} \mathrm{C}$. Suhu ini dapat menghasilkan polimerisasi molekul dalam bahan baku dimana molekul yang lebih besar dapat diproduksi dengan beberapa senyawa aromatik dan alifatik. Beberapa komponen bahan baku karena dekomposisi termal diubah menjadi molekul yang lebih kecil . Proses pirolisis mengubah bahan organik menjadi tiga komponen yang berbeda yaitu gas, cair dan padat. Dalam proporsi yang berbeda tergantung pada kedua bahan baku dan kondisi pirolisis .Gas-gas dan cairan dapat ditingkatkan dan digunakan sebagai bahan bakar untuk pembakaran . Komponen cair yang tersisa setelah pirolisis adalah asap cair [3].

Tabel 1. Kondisi Proses dan Produk yang Dihasilkan Pada Pirolisis [3]

\begin{tabular}{|c|c|c|c|c|c|}
\hline \multirow{2}{*}{$\begin{array}{c}\text { Proses } \\
\text { Pirolisis }\end{array}$} & $\begin{array}{c}\text { Waktu } \\
\text { Tinggal }\end{array}$ & $\begin{array}{c}\text { Tingkat } \\
\text { Pemanasan }\end{array}$ & $\begin{array}{c}\text { Suhu } \\
\left.\mathbf{(}^{\mathbf{O}} \mathrm{C}\right)\end{array}$ & $\begin{array}{c}\text { Arang } \\
(\%)\end{array}$ & $\begin{array}{c}\text { Asap } \\
\text { Cair } \\
(\%)\end{array}$ \\
\hline $\begin{array}{c}\text { Pirolisis } \\
\text { Lambat }\end{array}$ & $5-30 \mathrm{~min}$ & $50^{\mathrm{O}} \mathrm{C} / \mathrm{min}$ & $\begin{array}{c}400- \\
600\end{array}$ & 35 & 30 \\
\hline $\begin{array}{c}\text { Pirolisis } \\
\text { Cepat }\end{array}$ & $5 \mathrm{~s}$ & $200^{\circ} \mathrm{C} / \mathrm{s}$ & $\begin{array}{c}400- \\
600\end{array}$ & 25 & 75 \\
\hline $\begin{array}{c}\text { Pirolisis } \\
\text { Flash }\end{array}$ & $0,1 \mathrm{~s}$ & $200^{\circ} \mathrm{C} / \mathrm{s}$ & $\begin{array}{c}650- \\
900\end{array}$ & 20 & 70 \\
\hline
\end{tabular}

Refensi [4] menyampaikan faktor-faktor yang mempengaruhi proses pirolisis adalah:

\section{A. Suhu}

Suhu merupakan faktor yang sangat berpengaruh dalam proses pirolisis, karena proses perengkahan biomassa memerlukan energi kalor, semakin tinggi suhu, maka cairan yang diperoleh akan semakin besar, namun pada suhu tertentu kenaikan akan menurunkan hasil cairan yang diperoleh.

\section{B. Kecepatan Transfer Panas}

Kecepatan pemanasan yang tinggi diperlukan untuk menjamin ketersediaan kalor reaksi pirolisi yang berlangsung cepat. Semakin besar kecepatan pemanasan, maka hasil cairan yang diperoleh semakin besar sedangkan padatan semakin kecil.

\section{Waktu Tinggal Gas Hasil Pirolisis}

Char yang dihasilkan merupakan katalis pada proses cracking, waktu tinggal gas yang lebih lama akan memberikan kesempatan terjadinya cracking kedua sehingga hasil cairan akan semakin rendah, sedangkan hasil padatan akan semakin besar.

\section{Ukuran Partikel}

Pengaruh ukuran partikel pada proses pirolisis akan paralel disertai partikel panas dalam butiran. Ukuran partikel yang kecil membuat panas mudah tersebar secara merata keseluruh bagian sedangkan semakin besar ukuran partikel maka pemanasan akan berlangsung lambat sehingga suhu rata-rata pada partikel akan lebih rendah dan mengakibatkan hasil cairan yang diperoleh lebih sedikit.

Tabel 2. SNI Asap Cair [5]

\begin{tabular}{|l|c|}
\hline \multicolumn{1}{|c|}{ Parameter } & SNI Asap Cair \\
\hline Rendemen & - \\
\hline Ph & $1,5-3,0$ \\
\hline Total Asam Tertitrasi & $4,5-15,0$ \\
\hline Kadar Fenol & $4,6-15,0$ \\
\hline Berat Jenis & Minimal 1,001 \\
\hline
\end{tabular}

Tabel 3. Kualitas dan Kuantitas Asap Cair pada Berbagai Grade [6]

\begin{tabular}{|c|l|c|c|}
\hline \multirow{2}{*}{ No } & \multirow{2}{*}{ Sampel } & \multicolumn{2}{|c|}{ Kualitas } \\
\cline { 3 - 4 } & & Kadar Fenol (\%) & Kadar Asam (\%) \\
\hline 1 & Grade 1 & $6,4-7,8$ & $58,63-59,93$ \\
\hline 2 & Grade 2 & 6,4 & $43,96-44,24$ \\
\hline 3 & Grade 3 & $5,9-6,4$ & $8,08-18,92$ \\
\hline 4 & Grade 4 & $3,7-4,7$ & $4,15-9,65$ \\
\hline
\end{tabular}

Berdasarkan hasil penelitian yang dilakukan oleh [7] tentang kajian optimasi proses pirolisis tongkol jagung untuk produksi asap cair. Cairan pirolisis yang dihasilkan mengalami kenaikan dari suhu $408.53^{\circ} \mathrm{C}$ hingga $550^{\circ} \mathrm{C}$, kemudian menurun hingga suhu $691,42^{\circ} \mathrm{C}$. Dengan peningkatan suhu, akan terjadi peruraian komponen biomassa tongkol jagung, mulai dari hemiselulosa, selulosa, dan lignin. Peruraian yang semakin meningkat akan meningkatkan banyaknya gas yang dihasilkan. Gas ini akan terkondensasi sehingga menghasilkan cairan.

Penelitian [8] tentang kajian pirolisis tongkol dan kelobot jagung untuk identifikasi produksi bahan tambahan pangan (pengawet, flavour, antioksidan) dan bio oil. Hasil proses pirolisis ini berupa cairan, gas, dan padatan. Cairan hasil proses pirolisis merupakan gas 
yang terkondensasi. Banyaknya cairan yang dihasilkan meningkat dengan peningkatan suhu dari $250{ }^{\circ} \mathrm{C}$ sampai suhu $550{ }^{\circ} \mathrm{C}$ dari $19,69 \%$ menjadi $39,13 \%$, meningkat sebanyak 19,44\%. Pada suhu $700{ }^{\circ} \mathrm{C}$ cairan yang dihasilkan mengalami penurunan dibandingkan dengan suhu $550{ }^{\circ} \mathrm{C}$, dari $39,13 \%$ menjadi $29,73 \%$ menurun sebanyak $9,40 \%$.

\section{Metode Penelitian}

\section{A. Alat dan Bahan}

a. Alat

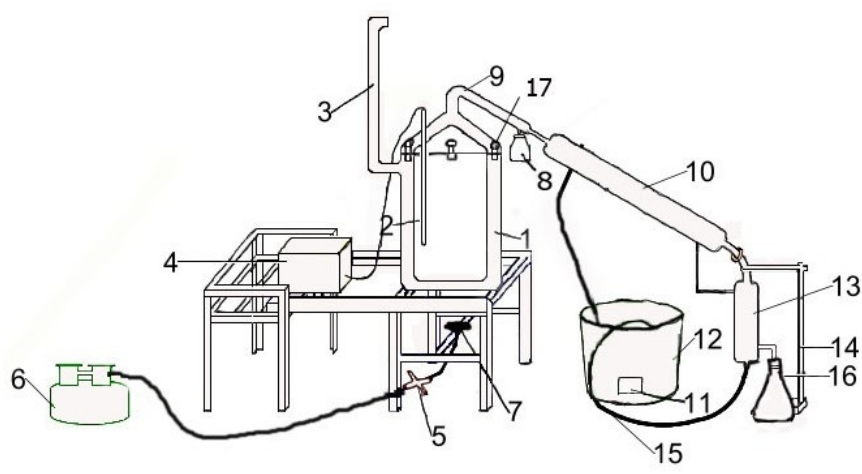

Gambar 1. Rangkaian Alat Pirolisis

Keterangan Gambar :

1. Reaktor pirolisis

10. Kondensor

2. Pipa pengontrol suhu

11. Pompa

3. Pipa cerobong pengeluaran asap

4. Termocople

12. Water Tank

5. Pengontrol nyala api

13. Katup

6. Tabung gas

14. Tiang penyangga

7. Tungku pembakaran gas

8. Penampungan tar

15. Selang

16. Penampung asap cair

9. Penutup reaktor pirolisis

17. Skrup

b. Bahan

Bahan baku yang digunakan yaitu limbah tongkol jagung yang diperoleh dari Kabupaten Bone.

\section{B. Variabel Penelitian}

a. Suhu

: $350{ }^{\circ} \mathrm{C}, 400{ }^{\circ} \mathrm{C}, 450{ }^{\circ} \mathrm{C}$ dan $500^{\circ} \mathrm{C}$

b. Waktu Tinggal

: 30 menit, 60 menit, 90 menit, 120 menit, 150 menit dan 180 menit

c. Ukuran

: $\operatorname{kasar}(-1 /+1,5$ inchi), sedang $(-3 / 8 /+1$ inchi $)$ dan halus $(-1 / 4 /+3 / 8$ inchi). $(0,1$ inchi $=20$ mesh $)$

\section{Prosedur Penelitian}

a. Persiapan Bahan Baku

Proses persiapan bahan baku dimulai dengan membersihkan bahan baku tongkol jagung dari pengotornya kemudian dijemur hingga kering dibawah sinar matahari langsung selama 3 hari. Serbuk gergaji tongkol jagung kemudian dicacah berdasarkan ukurannya yaitu kasar $(-1 /+1,5$ inchi), sedang $(-3 / 8 /+1$ inchi) dan halus $(-1 / 4 /+3 / 8$ inchi) .

\section{b. Proses Pirolisis}

Limbah tongkol jagung ditimbang sebanyak 1 $\mathrm{kg}$, dimasukkan kedalam reaktor dengan membuka bagian atas reaktor yang sebelumnnya telah dibersihkan. Kemudian menutup reaktor dengan rapat agar tidak ada bagian yang bocor. Setelah itu menyalakan pompa air pendingin dan pemanas reaktor serta mengeset suhu pemanas pada suhu yang diinginkan yaitu 350, 400, 450, dan $500{ }^{\circ} \mathrm{C}$ pada thermocontrol yang telah terhubung dengan arus lstrik, serta memasang botol penampung asap cair.

Proses pirolisis dilakukan dengan variasi waktu tinggal 30, 60, 90, 120, 150 dan 180 menit dengan variasi ukuran tongkol jagung yaitu kasar $(-1 /+1,5$ inchi), sedang $(-3 / 8 /+1$ inchi) dan halus $(-1 / 4 /+3 / 8$ inchi).

\section{c. Analisis Asap Cair}

Proses analisa asap cair dilakukan secara fisika dan kimia. Variabel - variabel yang ditentukan melalui analisa asap cair dari proses pirolisis limbah tongkol jagung yaitu analisa rendemen, $\mathrm{pH}$, berat jenis, total asam tertitrasi dan analisa kadar fenol.

\section{Hasil dan Pembahasan}

\section{A. Pengaruh Suhu Terhadap Yield Asap Cair}

Pengaruh suhu pada proses pirolisis limbah tongkol jagung dapat dilihat pada gambar 2. Berdasarkan grafik tersebut kenaikan yield asap cair terlihat signifikan dari suhu $350^{\circ} \mathrm{C}$ hingga $400^{\circ} \mathrm{C}$ yaitu sebesar $4,7 \%$ sedangkan pada suhu $450^{\circ} \mathrm{C}$ dan $500^{\circ} \mathrm{C}$ yield asap cair yang dihasilkan cenderung konstan dengan penurunan hanya sebesar $0,5 \%$. Berdasarkan hasil tersebut maka suhu optimum proses pirolisis yaitu pada suhu $400^{\circ} \mathrm{C}$, dengan peningkatan suhu, akan terjadi peruraian komponen 
biomassa tongkol jagung, mulai dari hemiselulosa, selulosa, dan lignin. Peruraian yang semakin meningkat akan meningkatkan banyaknya gas yang dihasilkan. Gas ini akan terkondensasi sehingga menghasilkan cairan. Cairan yang dihasilkan sebagian besar terdiri dari air sebagai pelarut.

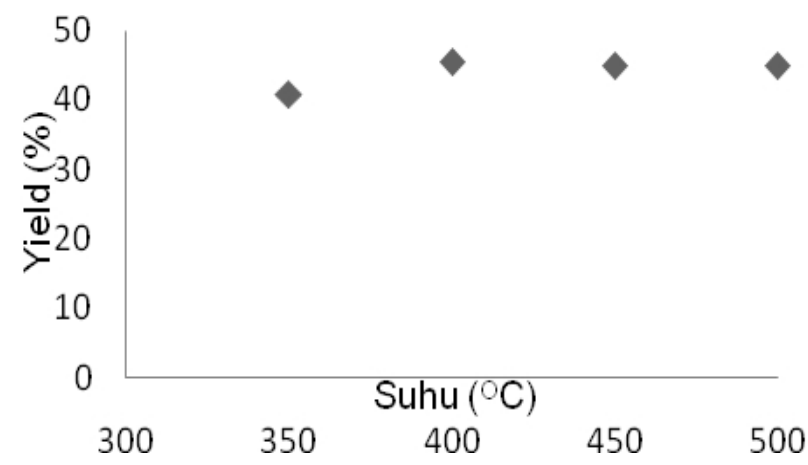

Gambar 2. Grafik Hubungan Antara Suhu dan Yield Asap Cair Tongkol Jagung

Bahan baku tongkol dan kelobot jagung menghasilkan suhu optimum $550^{\circ} \mathrm{C}$ berbeda dengan penelitian yang telah dilakukan dengan suhu optimum $400^{\circ} \mathrm{C}$. Hal ini dikarenakan pada penelitian sebelumnya menggunakan katalis atapulgit untuk mencapai suhu yang lebih tinggi selain itu kondisi alat hanya mampu mencapai suhu $490^{\circ} \mathrm{C}$ [7] dan [8].

Pirolisis pada suhu $400^{\circ} \mathrm{C}$ menghasilkan senyawa yang mempunyai kualitas organoleptik yang tinggi dan pada suhu lebih tinggi lagi akan terjadi reaksi kondensasi pembentukan senyawa baru dan oksidasi produk kondensasi diikuti kenaikan linier senyawa tar dan hidrokarbon polisiklis aromatis.

\section{B. Pengaruh Waktu Terhadap Yield Asap Cair}

Waktu merupakan faktor yang berpengaruh pada proses pirolisis. Waktu tinggal yang lebih lama akan memeberikan kesempatan terjadinya cracking kedua sehingga akan mempengaruhi yield asap cair. Berdasarkan hasil karakterisasi gambar 2 diperoleh suhu optimum proses pirolisis asap cair tongkol jagung yaitu pada suhu $400^{\circ} \mathrm{C}$. Suhu tersebut kemudian dijadikan acuan untuk menentukan waktu optimum proses pirolisis asap cair tongkol jagung.

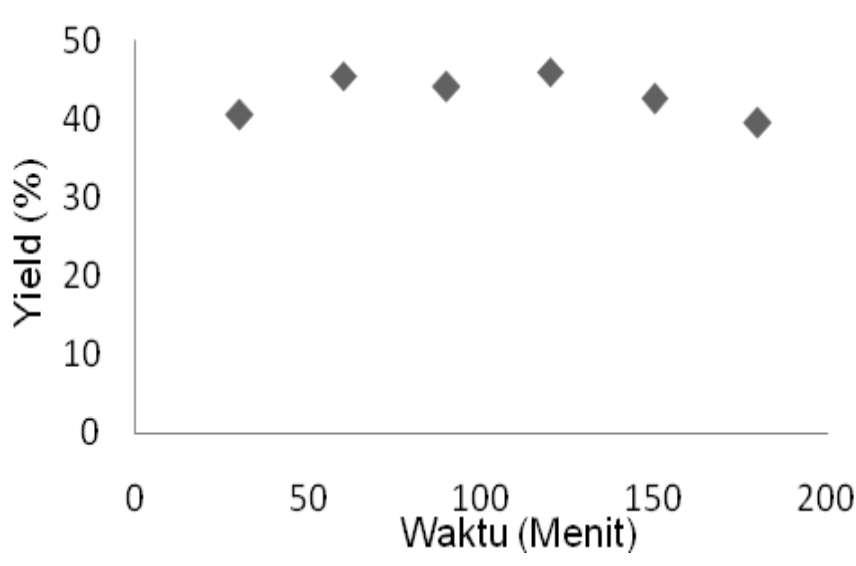

Gambar 3. Grafik Hubungan antara Waktu Terhadap Yield Asap Cair Tongkol Jagung

Grafik hubungan antara waktu terhadap yield asap cair berdasarkan gambar 3 menunjukkan hasil yield asap cair yang sangat bervariasi. Kenaikan yield asap cair yaitu pada waktu 30 menit sampai 60 menit yaitu sebesar 5\%, kemudian menurun sampai pada waktu 120 menit yang merupakan waktu optimum yang diperoleh pada penelitian ini dengan yield sebesar $46 \%$. Yield asap cair yang dihasilkan kemudian mengalami penurunan yang cukup signifikan sampai pada waktu 180 menit dengan yield sebesar $39,5 \%$. Berdasarkan hasil tersebut yaitu pada suhu $400^{\circ} \mathrm{C}$ dan waktu 120 menit menghasilkan asap cair yang optimum dikarenakan tongkol jagung mendapatkan jumlah panas terbanyak dengan waktu paling lama sehingga unsur-unsur dalam tongkol jagung semakin banyak yang terurai dan terkondensasi menjadi asap cair. Sedangkan penurunan yield asap cair sampai pada waktu 180 menit. karena banyak senyawa-senyawa asap cair yang tak terkondensasi dan bersifat volatile (misalnya hydrogen, metana, karbon monoksida dll).

Menurut [4], Char yang dihasilkan merupakan katalis pada proses cracking, waktu tinggal gas yang lebih lama akan memberikan kesempatan terjadinya cracking kedua sehingga hasil cairan akan semakin rendah, sedangkan hasil padatan akan semakin besar.

\section{Pengaruh Ukuran Terhadap Yield Asap Cair}

Pengaruh ukuran partikel sangat berpengaruh terhadap proses pirolisis limbah tongkol jagung. Variasi ukuran yang diamati pada penelitian ini yaitu ukuran halus, sedang dan kasar. Berdasarkan hasil karakterisasi 
gambar 2 dan 3 diperoleh suhu optimum proses pirolisis asap cair tongkol jagung yaitu pada suhu $400^{\circ} \mathrm{C}$ dengan waktu optimum yaitu 120 menit. Suhu dan waktu optimum tersebut kemudian dijadikan acuan untuk menentukan ukuran optimum proses pirolisis asap cair tongkol jagung.

Tabel 4. Pengaruh Ukuran Terhadap Cairan Hasil Pirolisis Tongkol Jagung $\left(\mathrm{T}=400{ }^{\circ} \mathrm{C}, \mathrm{t}=120\right.$ Menit)

\begin{tabular}{|c|c|}
\hline $\boldsymbol{\theta}$ (Inci) & Yield (\%) \\
\hline Kasar (1.5) & 42 \\
\hline Sedang (1) & 45.5 \\
\hline Halus (3/8) & 47 \\
\hline
\end{tabular}

Pengaruh ukuran merupakan faktor yang sangat berperan dalam proses pirolisis limbah tongkol jagung, dari hasil penelitian yang disajikan dalam tabel 4 diperoleh ukuran optimum pirolisis asap cair dari tongkol jagung yaitu pada ukuran halus $3 / 8$ inci dengan yield sebesar $47 \%$. Sedangkan pada ukuran kasar 1,5 inci mengalami penurunan yaitu sebesar $42 \%$.

Ukuran halus (3/8 inci) menghasilkan asap cair yang optimum dikarenakan semakin kecil ukuran partikel suatu bahan maka akan semakin mudah bahan tersebut terdekomposisi dan terkondensasi menjadi asap cair. Sedangkan pada ukuran kasar (1,5 inci) mengalami penurunan karena butuh waktu yang lama untuk terdekomposisi menjadi asap cair.

Menurut [4] pengaruh ukuran partikel pada proses pirolisis akan paralel disertai partikel panas dalam butiran. Ukuran partikel yang kecil membuat panas mudah tersebar secara merata keseluruh bagian sedangkan semakin besar ukuran partikel maka pemanasan akan berlangsung lambat sehingga suhu ratarata pada partikel akan lebih rendah dan mengakibatkan hasil cairan yang diperoleh lebih sedikit.

\section{Penentuan Grade Asap Cair}

Tabel 5. Sifat Fisik dan Kimia Asap Cair Tongkol Jagung

\begin{tabular}{|c|r|c|c|c|c|}
\hline Variabel & $\begin{array}{c}\text { Rendemen } \\
(\mathbf{\%})\end{array}$ & $\begin{array}{c}\text { Berat } \\
\text { Jenis } \\
(\mathbf{g r} / \mathbf{m l})\end{array}$ & $\mathbf{p H}$ & $\begin{array}{c}\text { Total } \\
\text { Asam } \\
(\mathbf{\%})\end{array}$ & $\begin{array}{c}\text { Kadar } \\
\text { Fenol } \\
(\mathbf{\%})\end{array}$ \\
\hline $\mathbf{T} \mathbf{( \mathbf { O } )}$ & & & & & \\
\hline 350 & 40.8 & 1.0305 & 1.8 & 7.2343 & 4.1569 \\
\hline 400 & 45.5 & 1.0311 & 1.8 & 6.9410 & 3.7123 \\
\hline
\end{tabular}

\begin{tabular}{|c|r|r|r|r|c|}
\hline 450 & 45 & 1.0302 & 1.8 & 7.0153 & 3.7565 \\
\hline $490 / 500$ & 45 & 1.0323 & 1.9 & 6.8054 & 3.8012 \\
\hline t (menit) & & & & & \\
\hline 30 & 40.5 & 1.0320 & 1.9 & 7.2746 & 4.0235 \\
\hline 60 & 45.5 & 1.0311 & 1.8 & 6.9410 & 3.7123 \\
\hline 90 & 44 & 1.0316 & 1.9 & 6.8351 & 3.6678 \\
\hline 120 & 46 & 1.0315 & 1.9 & 7.0564 & 3.6234 \\
\hline 150 & 42.5 & 1.0315 & 1.8 & 6.8980 & 3.4900 \\
\hline 180 & 39.5 & 1.0319 & 1.8 & 6.9151 & 3.4456 \\
\hline $\begin{array}{c}\text { Ukuran } \\
\text { (inci) }\end{array}$ & & & & & \\
\hline $\begin{array}{c}\text { Halus } \\
(3 / 8)\end{array}$ & 47 & 1.0284 & 1.8 & 7.2237 & 3.9346 \\
\hline $\begin{array}{c}\text { Sedang } \\
(1)\end{array}$ & 45.5 & 1.0315 & 1.9 & 7.0564 & 3.6234 \\
\hline $\begin{array}{c}\text { Kasar } \\
(1,5)\end{array}$ & 42 & 1.0347 & 1.9 & 7.1404 & 3.0899 \\
\hline
\end{tabular}

Berdasarkan tabel 3 kualitas dan kuantitas asap cair pada berbagai grade maka asap cair yang diperoleh pada penelitian ini yaitu masuk dalam kategori grade 4 yaitu pada kuantitas atau rendemen sebesar 15,9\% - 45,5\% dan kadar asam sebesar $4,15 \%-9,65 \%$ dan kadar fenol sebesar 3,7\% - 4,7\%, ini dikarenakan asap cair yang diperoleh pada penelitian ini merupakan asap cair yang murni tanpa perlakuan khusus seperti destilasi atau pemakaian zat kimia lain untuk menaikkan grade asap cair tongkol jagung.

\section{Kesimpulan}

1. Suhu optimum yang diperoleh pada proses pembuatan asap cair dari limbah tongkol jagung dengan metode pirolisis lambat yaitu pada suhu $400^{\circ} \mathrm{C}$ dengan yield sebesar $45,5 \%$.

2. Waktu optimum yang diperoleh pada proses pembuatan asap cair dari limbah tongkol jagung dengan metode pirolisis lambat yaitu pada waktu operasi 120 menit menghasilkan yield sebesar $46 \%$.

3. Ukuran optimum yang diperoleh pada proses pembuatan asap cair dari limbah tongkol jagung dengan metode pirolisis lambat yaitu pada ukuran tongkol jagung halus menghasilkan yield sebesar $47 \%$

4. Grade asap cair yang diperoleh pada penelitian pembuatan asap cair dari limbah tongkol jagung dengan metode pirolisis lambat yaitu grade 4 . 


\section{Daftar Pustaka}

[1] Anggraeny, Y. N., U. Umiyasih, dan D. Pamungkas. 2006. Pengaruh Suplementasi Multi Nutrient terhadap Performans Sapi Potong yang Memperoleh Pakan Basal Jerami Jagung. Pros. Sem. Nas. Teknologi Peternakan Veteriner. p. 147-152

[2] Sonobe et al, 2006. Pyrolysis Characteristic of Thai Lignite and Biomass Blends : An In-depth Experimental Investigation. The Second Joint International Conference on "Sustainable Energi and Environment (SEE)" 21-23 November 2006, Bangkok, Thailand

[3] Kanyaphorn Chaiwong and Tanongkiat Kiatsiriroat. 2015. Characterization of Bio-Oil and Bio-Char Products from Algae with Slow and Fast Pyrolysis. International Journal of Environment and Bioenergy,2015,10(1):65-76.
[4] Raveendran, K., A. Ganesh, and K. C. Khilar. 1996. Pyrolysis Characteristics of Biomass and Biomass Components. Journal of Fuel Vol. 75 No. 8, pp. 987- 998. Elsivier Applied science Publisher, Great Britain.

[5] Pamori, dkk. 2015. Karakteristik Asap Cair dari Proses Pirolisis Limbah Sabut Kelapa Muda. SAGU. Vol. 14 No.2:43-50

[6] Erliza Noor, Candra Luditama, Gustan Pari, 2010, Isolasi dan Pemurnian Asap Cair Berbahan Dasar Tempurung dan Sabut Kelapa Secara Pirolisis dan Distilasi, Pusat Penelitian dan Pengembangan Hasil Hutan Bogor.

[7] Purwaningtyas, Asri, 2010. Kajian Optimasi Proses Pirolisis Tongkol Jagung untuk Produksi Asap Cair, Skripsi.

[8] Choiriyah, Siti. 2010. Kajian Pirolisis Tongkol dan Kelobot Jagung Untuk Identifikasi Produksi Bahan Tambahan Pangan, Skripsi. 